\title{
Introduction
}

Patricia Vilches*

\section{Alberto Blest Gana: 100 Years Later}

https://doi.org/10.1515/culture-2021-0003

received January 26, 2021; accepted April 13, 2021

\begin{abstract}
Blest Gana at 100 is a special edition for Open Cultural Studies. Alberto Blest Gana was a Chilean writer who wore many hats during his long life, dying in 1920 at the age of 90 . One of the most prominent authors of nineteenth-century Chile and Latin America, he went to military school and later held political and diplomatic appointments, all of which caused him to travel and live abroad. In fact, nel mezzo del cammin of his life, Blest Gana transferred to Europe and eventually settled in Paris, never to return to his country of birth. His fiction and non-fiction conveyed a vast array of experiences and insights from his life in Chile and overseas. To commemorate the 100 years since his death, contributors to Blest Gana at 100 approach his oeuvre from innovative and fresh scholarly angles and thus generate new perspectives on the Chilean author's most celebrated texts, such as Martin Rivas and El ideal de un calavera. They also examine the early days of his literary career; revisit critical scholarship on Blest Gana from the past; bring less explored texts, such as Mariluán and Los Trasplantados (the latter written and published in Paris) to the foreground; research the background to his work as a columnist and discover the extent to which it informed his literary career; and examine the urban social practices in Blest Gana's award-winning novel La aritmética en el amor. From these analyses, we hope to foster an ongoing conversation of lively and invigorating Blest Gana scholarship.
\end{abstract}

Keywords: Blestganian, 100 commemoration, Chile, Paris

\section{A Place of Memory}

The remains of Alberto Blest Gana (1830-1920), “founder” of the Chilean novel, are not at Chile's Cementerio General de Santiago, an institution established in 1821 during the government of Bernardo O'Higgins (1778-1842). Called an "urban park" for its "varying architectural styles" that are typical of a multitude of "elegant, massive mausoleums"1 (Roselli), Santiago's Cementerio General bursts with history. It is Chile's official pantheon and one of the most remarkable lieux de mémoire [realms of memory] in the nation. It holds the remains of Chile's luminaries, such as presidents of the Republic, artists, creative writers, politicians, historians, and so on. ${ }^{2}$ Being interred there is a "sign of distinction and of group

1 Translation mine. All translations from Spanish to English are mine unless otherwise indicated. Quotations of Blest Gana are given in Spanish and English.

2 Political personality Clotario Blest Riffo (1899-1990), a nephew of the Chilean author, is buried at the Cementerio General de Santiago. Clotario Blest was the son of Ricardo Blest Ugarte, offspring of Guillermo Cunningham Blest (Alberto Blest Gana's father), from a second marriage (his first wife, María de la Luz Gana y López, mother of Alberto, died prematurely). Clotario Blest studied in the seminary to become a Catholic priest, following the Franciscan order; after attending the lectures of Luis Emilio Recabarren (1876-1924), leader of the workers movement in Chile, Clotario Blest abandoned the Franciscan order to become a social activist. He is known as a revolutionary, Christian humanitarian who had a pivotal role in fighting for workers' rights. For instance, he was crucial in the creation of the CUT in 1952. The CUT stands for Central Unica de Trabajadores [Unified Workers' Center]. Clotario Blest became its first president (“Clotario Blest Riffo").

\footnotetext{
* Corresponding author: Patricia Vilches, Spanish Department, Lawrence University, 711 E John St, Appleton, WI 54911, United States of America, e-mail: patricia.vilches@lawrence.edu
} 
membership" (Nora 12). One cannot, however, visit the tomb of Alberto Blest Gana at the Cementerio General. Instead, the Pater Patriae of Chilean Literature rests at Père Lachaise in Paris. Established in 1804, Père Lachaise is one of the most well-known cemeteries in the world, renowned for holding the remains of celebrities and luminaries such as Jim Morrison, Edith Piaf, and Oscar Wilde. Buried in a foreign land, Blest Gana shares a fate similar to Dante Alighieri, the celebrated author of the Divina Commedia (1321). ${ }^{3}$ With the remains of one of Chile's greatest authors in its distinguished grounds, Père Lachaise is more than a landmark for Chileans. It holds a constituent part of our patrimony and, in the words of Pierre Nora, is therefore one of our "ultimate embodiments of a memorial consciousness" (12).

Blest Gana at 100 commemorates and contextualises the life and career of Chile's most prominent nineteenth-century author for an English-speaking audience of specialists and generalists. Through biographical studies as well as essays on Chilean history, cultural studies, literary criticism, space studies, sensory and affect studies, this special edition of Open Cultural Studies pays homage to Alberto Blest Gana and his legacy 100 years after his death. Following various approaches, contributors have revisited Blest Gana's "classics," such as Martín Rivas (1862) and El ideal de un calavera [The Ideal of a Rogue] (1863) within new contexts. Or, they have probed the meaning of "sense" and "scent" (literally and metaphorically) in La aritmética en el amor [Arithmetic in Love/The Economics of Love] (1860), with a specific focus on people's habits and capitalistic attitudes. Others have brought lesser known works of fiction, such as Mariluán (1862) and Los Trasplantados [The Transplanted] [The Uprooted] (1904) to the foreground. In addition, contributors have highlighted and re-examined historical literary discussions from noted Blest Gana scholars. Contributors have revisited the coexistence of literary tensions in the author's oeuvre, which they find to be permeated by a sui generis type of realism that is intertwined with romanticism. This is an enduring topic of debate in Blest Gana scholarship. Finally, the role of the print press in the development of the Chilean author's work is investigated, with emphasis placed on its appearance in the popular folletines [feuilletons, newspaper serials] that emerged around the mid-1800s at the foot of in-vogue newspapers. Alongside French and other European authors - and in competition with them - Blest Gana and other Chilean writers participated in this practice, which in turn helped lay the foundation for the Chilean novel (Barraza 116).

\section{An Immigrant's Son}

Irish immigrants are prominent in the Chilean national landscape. Blest Gana shares the same Irish roots of Bernardo O'Higgins, one of the nation's founders. O'Higgins was the offspring of Chilean aristocrat Isabel Riquelme and the highly successful Irish immigrant Ambrose O'Higgins (1720-1801), or "Higgins," as he himself signed his name. ${ }^{4}$ Ambrosio, as he is known in Chile, left Ireland for Spain and later headed to the "New Continent" to escape the Protestant oppression of Irish Catholics. He sought to overcome and reverse an impoverished fate. Ambrosio demonstrated fortuna e virtù à la Machiavelli and successfully climbed the social echelons of a rigid colonial society, rising as high as he or any other Irish immigrant could, eventually being appointed Viceroy of Peru. ${ }^{5}$ Decades later, Blest Gana's father, William Cunningham Blest,

3 Founding "father" of the Italian language and venerated by Florentines, Dante died away from Florence and his final resting place is in Ravenna.

4 Bernardo O'Higgins was born out of wedlock. His name appeared on a birth certificate 5 years after his birth. Because he was an illegitimate child, and his mother belonged to a leading family from the city of Chillán, the name of his mother was withheld from the document. However, he was known by all as Bernardo Riquelme. Bernardo was helped financially by his father, especially with his education, which saw him travel to Europe and visit famous exiles in London. Nonetheless, Bernardo was never recognised as a legitimate child by Ambrosio. He adopted the O'Higgins last name only after his father's death (Kinsbruner 21, 24-25, 31). 5 Ambrose O'Higgins left for Spain in 1751. By 1786, he had become a prominent political figure in the Kingdom of Chile. According to historian Alfredo Sepúlveda, this accomplishment "was already extraordinary, for although certain foreigners and especially Irish Catholics - enjoyed the favour of the crown, obtaining a high position in the bureaucracy [of Spain] was something reserved for peninsular families of the highest lineage" (165). 
immigrated to Chile from Sligo, the same county of origin as Ambrosio O'Higgins. He was motivated by the reputation of Bernardo O'Higgins's government for welcoming European immigrants whose intellectual abilities would contribute to the consolidation of the young nation. Cunningham Blest was following in the footsteps of two other siblings who had previously disembarked for Latin America. Arriving at the port of Valparaíso towards the end of 1823 or beginning of 1824 - around the time Bernardo O'Higgins was forced to leave office - Cunningham Blest headed for Santiago, eager to learn about his new nation. He was a physician by profession who had studied medicine at Trinity College in Dublin and later specialised in obstetrics and gynaecology at the University of Edinburgh. Once established in Chile, he married aristocrat María de la Luz Gana y López and had a large family (Silva Castro, Blest Gana 9-10, 20). Alberto, the couple's third child, was born the year the pipiolos [liberals] were defeated by the pelucones [conservatives] in the bloody Battle of Lircay, which was fought among deeply divided Chileans. The major outcome of this battle was the establishment of a "new" conservative order (Sepúlveda 298). In his new country, Cunningham Blest befriended the intellectual and political luminaries of the time and was instrumental in modernising the teaching of medicine in Chile (Hosiasson, "Alberto Blest Gana" 39-40; Silva Castro, Blest Gana, 9-10). Blest Gana had two other famous brothers: Guillermo, a prominent Romantic poet; and José Joaquín, a politician, lawyer, and journalist. Alberto and his siblings grew up in an environment of great intellectual stimuli.

\section{"Birth" of the Chilean Novel}

According to cultural critic Juan Poblete, Blest Gana and other Latin American writers adjusted the European models of the time for a national audience, perceiving "the national novel as an intermediate form half-way between the complexities of high culture and the supposed banalities of popular and frivolous literature" ("Reading” 323). Sir Walter Scott had developed a substantial audience among Chileans (these readers, as one would expect, were mostly members of the elite), inspiring sentiments of nationhood which were also conveyed in the works of Ramón López Soler and Luis de Espronceda, among others (Cánepa 250). By 1850, intellectuals were calling for a properly Chilean novel. Letrados such as Francisco Bilbao (1823-1865), ${ }^{6}$ José Victorino Lastarria (1817-1888), ${ }^{7}$ and the brothers Justo and Domingo Arteaga y Alemparte felt that, above all other modes of fiction, the novel was the most appropriate means "to create a profile of Chilean literature" (Subercaseaux 136). For Lastarria, particularly, an established current of intellectual thought was critical to the progress of the nation. He declared, "let us put our literary memoirs in order, with a view to testify in the judgment of the evolution of Chilean thought" (Lastarria 2).

The Universidad de Chile organised a literary contest to promote the development and establishment of a national novel, one that would raise up an author capable of "deep observation" who could perceive and contemplate a "spirit of continuity" in the nation's progress. In its contest guidelines, the Universidad de Chile specified that the winning novel was principally and intrinsically required to recount a subject that pertained to Chile, its history, and its people's customs. Winning the literary contest in 1860 with $L a$ aritmética en el amor, Blest Gana took a significant step forward in a literary career that would bear other fruitful professional results (Silva Castro, Blest Gana 188-189). In an exhortative 1861 speech on the occasion of his election as a facultativo to the Universidad de Chile, he addressed the state of the Chilean nation.

6 Bilbao was an elite member of society with family ties to the pipiolo cause. He was the author of La sociabilidad chilena [Chilean Sociability] (1844), in which he denounced the conservative, stagnant, and unfair ways in which society functioned in Chile. The importance of the text can be measured according to its impact: it was censured and burnt, and its author was prosecuted and forced into exile (Poblete, Literatura 72). Bilbao became a member of the Sociedad de la Igualdad [Society of Equality], created in 1850. The Sociedad de la Igualdad features prominently in Martín Rivas.

7 Lastarria was one of Chile's most prominent letrados. He was an academic, a politician, and a diplomat, exercising influence over others, such as Blest Gana himself, on the immediate, "national," need for Chileans to be educated. He used the print press to express his views, for example in El Semanario. As I have said elsewhere, in these Semanario columns Lastarria anticipated the ironic tone of Chile's contemporary newspaper The Clinic (Vilches, Blest Gana 18). 
Honouring the memory of Juan Bello (son of eminent letrado Andrés Bello), Blest Gana did not conceal his criticism of Chileans' mores, especially their preoccupation with materialistic pursuits, and he also criticised their lack of educational goals and intellectual curiosity. This would remain an issue throughout his academic career. As late as 1847, regulations allowed for literature and philosophy to be taught at the university level. In the teaching philosophies at the Universidad de Chile at the time, however, there was mounting tension around the question of general vs specialised education. Andrés Bello, the university's first rector, had pushed for a "classical" training for all, but he was restrained by the general majority (Serrano 128).

Blest Gana was aware of his audience. Chileans were reputed to lack serious or sustained reading habits and to show contempt for anything produced at home, preferring "a bad translation of a bad French book" to a good, original Chilean tome on national events (Arteaga y Alemparte 437). The author aspired to lofty goals and believed that Chile was entering the stages of adulthood where it might find value in the ideas of its own people (Blest Gana, "Literatura chilena" 85). Already with La aritmética en el amor, he had established his own demanding premises for fiction writing, "developing a main action intertwined by various secondary actions and bringing to life a large number of characters that would connect with each other" (Poblete Varas 75). He specified that Chileans needed to stop lowering their sights to mediocre goals and instead should advance a "genuine" national project. Alluding to Juan Bello's remarkable career, he took the opportunity to note that the rewards bestowed upon an individual with a sophisticated education such as Bello were ephemeral at best in his society. He articulated the need for Chileans to pursue higher ambitions that would put the country on the map. For him, Chileans had become too accepting of the standards and products of other nations, embracing whatever cultural artefact emanated from Europe, from books and intellectual ideas, to industry, the arts, and commerce (Blest Gana, "Literatura chilena" 81-83).

\section{Martin Rivas and the Chilean Nation}

Nora describes how the Tour de la France par deux enfants (1877) embodies an irrefutable lieu de mémoire for the French nation. It has "trained the memory of millions of French boys and girls" (20). Chile finds its own lieu de mémoire in Martín Rivas. A search for "Martín Rivas" in the National Curriculum menu on the website of the Chilean Ministry of Education yields more than 50 results ("Recursos educativos"). In one of those results, it is claimed that the novel remains required reading for young minds, in their first or second year of high school. Virtually all Chileans who have completed their formal education in Chile have read Blest Gana's novel. The Ministry of Education has now digitalised it, and the novel can be easily accessed and borrowed simultaneously, for educational purposes. Martín Rivas provides an imagined community for Chilean citizens, the image of our communion, as Benedict Anderson has asserted (5). It draws us in with indelible characters, love and heroics, as well as a depiction of the socio-political foundations of the nation's consolidation (Sommer 6, 214). It should be noted, however, that the novel's early reception did not include the type of acclaim it came to enjoy later, towards the turn of the century (Hosiasson, "El caleidoscopio" 144). Martín Rivas, all the same, is now recognised as one of the most read and popular novels in Chile:

This best seller of urban Chilean culture, read by generations and generations of our nation's schoolchildren, is rich in polite dialogues and soirees scenes and also manages to display all the elements of a good, popular story: intrigue, betrayal, contempt, armed conflict, imprisonment, humour, ridiculousness, conflicted love affairs, ambition for money, and most important of all, relationships unfailingly marked by class differences ("Recursos educativos”).

The text exemplifies a place and a moment in time, a veritable "embodiment of memory [...] where a sense of historical continuity persists" (Nora 7). Confronted by historical events and the trials of daily life, Martín, a provinciano from Copiapó, a city in the Northern part of the country, finds himself in the space of Santiago. It has been said that he is "a kind of Chilean Julien Sorel," the intelligent, ambitious, and proud character 
created by Stendhal (Collier and Sater 101). Undoubtedly, Martin possesses all the good qualities of Sorel and none of the bad ones. In the city, Martín will either swim or sink. Throughout, his performance is perfection itself (even when he defies good judgment), as he deftly and bravely navigates the turbulent waters of Santiago's society. Some critics have claimed that Martín may be "too good;" he conducts his life in "an irreproachable manner, perhaps too irreproachable" (Alone 154). Newly arrived in Santiago, he participates in, or is witness to, the struggles of Chileans engaged in conflicting debates over the conception of their nation. As the narration makes very clear, things are amiss: "No hubo tal vez una casa de Chile donde no resonara la descompuesta voz de las discusiones políticas, ni una sola persona que no se apasionase por alguno de los bandos que nos dividieron" [There was perhaps not a house in Chile where the decomposed/disembodied voice of political discussions did not resonate. Nor was there one person who would not become impassioned over one of the political factions that divided our country] (Blest Gana, Martin Rivas 114-115). Agitated discussions at tertulias [soirees] testify how the Chile of the 1850s was a nation of enemies; this circumstance and status would replicate itself in the 1970s when society again became deeply polarised by the ruptured political ideologies (Constable and Valenzuela 20, 21). For his part, Martín did not shy away from political discussions, sharing his liberal views and opposition to strong governments, for instance, during doña Engracia Nuñez's tertulias. Overall, Martín Rivas himself was unrivalled. He was timid, to be sure. But he was a man's man and deployed Machiavellian patriotism and superior intellectual skills to reach his goals (Vilches, "Martín Rivas" 71-72).

It has been said that Blest Gana conceived his meritorious characters as engaged, educated members of the middle class capable of effectuating a positive and uplifting turn in society. Martín Rivas, of course, possessed all of these qualities and was helped by a generous amount of fortuna, in the Machiavellian sense. According to Jaime Concha, the astounding success of Martín coalesces, above all, in a perfect rendering of the bourgeoisie in its three distinct formulations, namely, economics, politics, and spirituality, making the novel "an ontological discussion of the bourgeoisie" $(23,24)$. Other characters (and we may include some from other Blest Gana novels) were fashioned less praiseworthily by the author. They remained practical, basic, or even superficial, fighting for society's spotlight at whatever cost, hoping that ostentation itself (if they acquired new wealth) would elevate them to the heavens of universal elegance (Duran Luzio 921). The author delighted in constructing embarrassing or, rather, ridiculous situations for his less worthy characters, where he could place their honour at stake. Some would succumb irremediably, but others, for some reason or other, were just barely saved from social ostracism. Martín Rivas, however, dazzled everyone and achieved each one of his goals.

\section{Stages of Authorship}

In 1870, Blest Gana was described by the Arteaga y Alemparte brothers as a tempered individual who behaved according to the golden mean, the desirable state extolled by the ancient philosophers of the West. It was an account that fitted well with the designs of an author who became the main narrator of the Chilean nation. The brothers celebrated the author's style, which was endowed with a masterful, spontaneous, lively, colourful palette and tone that channelled and portrayed ideas with a "gentle scepticism" as well as a "delicate wit" (436). Blest Gana was represented as a Martín Rivas type of individual that gave his all in pursuit of excellence:

sixteen to eighteen years ago, a young man of a strong and a rather martial disposition distinguished himself in the elegant salons of Santiago. He had impeccable and nonchalant manners and knew how to dance perfectly. He knew how to converse amiably with the ladies and discreetly with the gentlemen. That was don Alberto Blest Gana. He had returned from France of recent, where the Chilean government had sent him, together with some of his classmates from the Military School, to complete his professional studies, where he had become a good staff officer. But a military career did not present any incentives for his ambitious goals. He abandoned it promptly to occupy a vacancy in the Ministry of War. He held the same position for many years, a fact that can be explained simply when one considers the poor conditions for promotion endured by a civil servant in our nation. On the one hand, he did not seem too keenly interested in the political militancy of the time; on the other hand, his intelligence, efficiency and laboriousness made him a highly valued worker in that State office (434). 
The Arteaga y Alemparte brothers emphasised that Blest Gana's life had different iterations: military man, civil servant, and author. To pursue his diplomatic career, he and his family left Chile for good at the end of 1866, by which time he had solidified his status as an author in his home country. He had a brief stay in Washington D.C., which catapulted him into a dual diplomatic position in London and Paris and anywhere else in Europe the Chilean government needed him (Silva Castro, Blest Gana 61-80). ${ }^{8}$ Working on behalf of the Chilean government, Blest Gana threw himself into each assignment in a committed and industrious way, leaving a copious amount of writing that overflowed many filing cabinets, with reports, opinions, and news for friends and associates (Araya 30). He immersed himself so deeply into his diplomatic work that he did not publish any fiction over a period of more than 30 years. This prolonged hiatus has been famously called Blest Gana's "period of catalepsy" by Alone, the pseudonym of Chilean literary critic and historian Hernán Díaz Arrieta (174). Some critics treat these intervals as two (or three) different stages in the author's creative production, while others recognise a type of mental switch, or mindfulness, that allowed him "to be present” and thus apply his diligent and curious personality to the task at hand. Blest Gana's knack for observing human nature thus passed from his fiction writing to his work as a diplomat, as critics generally recognise. They also note that, notwithstanding his meandering professional path, the author essentially maintained a consistent set of aesthetics throughout his literary career (Araya 33).

Guillermo Gotschlich has conceptualised "two historical periods” in the development of Blest Gana's novels. In the beginning is fiction that describes "the end of colonialist dependence." This is followed by literature illustrating Chile's transition towards institutional freedom as it gains its own sense of itself as a nation (53). With his historical novel Durante la Reconquista (1897), Blest Gana's return to publishing was spectacular. Recounting Spain's brief reconquest of the kingdom of Chile (1814-1817), the lengthy work took him 10 years to complete, which he did after resigning his commission as a diplomat. Blest Gana had been incensed by a letter from President Balmaceda who was acting on the advice of his brother José Ezequiel Balmaceda. The President's brother was moved by feelings of antipathy towards Blest Gana and wanted him removed from his diplomatic position, perhaps to accommodate a close acquaintance or a relative (Jaksić and Durán 18). In an atmosphere of "palace intrigue" or impeachment-style complaints (Álvarez 129), José Ezequiel stated that having lived too long in Paris, the author had become deschilenizado [De-Chileanised] (Poblete Varas 205, 206). ${ }^{9}$ In reply, Blest Gana used his historical novel to send an unquestionable message: no matter how long he had resided abroad, he had not lost his "Chileanness." Durante la Reconquista featured heroic fictional patriots as well as historical, mythical figures of Chilean Independence, like Manuel Rodríguez, Bernardo O’Higgins, and José Miguel Carrera. It demonstrated that Chile had always been foremost in Blest Gana's mind, even as he put down roots in Paris (Alone 176). The novel contains unquestionably French aspects, of course, and contemporary readings have identified those moments where its "chilenidad has been forged, imagined, and lived outside of Chile" (Álvarez 137).

The Arteaga y Alemparte brothers and others perceived a type of political aloofness in Blest Gana and they judged this to be enmeshed in his narrative style. It has been said that although aware of the political upheavals of his time, he was not easily moved by contemporary political events. Blest Gana has been characterised as an intellectual with liberal ideas who situated himself "in a corner" to observe and take

8 Silva Castro notes that "by decree of 1st December 1869, [Blest Gana] was placed in charge of the Chilean legation before Emperor Napoleon III, with residence in Paris. On 13th March 1870, upon being officially received by Napoleon in the Palace of the Tuileries, he began a diplomatic career of seventeen years, which are considered to be among the most significant years in the history of Chilean diplomacy" ("La obra” 330-331).

9 In a letter to President Balmaceda, Blest Gana defended himself from the accusation of being deschilenizado: "En cuanto a que un hombre se desnacionalice porque reside muchos años fuera de Chile, Ud. me permitirá que no considere el cargo como apoyado en ningún fundamento sólido. Acaso podría decirse eso del que se mantiene muchos años alejado del suelo natal por puro gusto. Mas, no es posible formular semejante acusación contra el que vive ocupado del servicio de su patria" [As for a man that is called denationalised because he resides for many years outside of Chile, you will allow me to consider this charge as being unsupported by any solid grounds. Perhaps one could say this of someone who remains many years away from his native land on a sheer whim. But it is not possible to level such an accusation against someone who occupies himself solely in the service of his country] (Epistolario 778; 886). 
note of society (Latcham 30-31; Poblete Varas 93). In this way, he comes across as an Abel Malsira type, from Durante la Reconquista, someone who kept his distance from or, rather, maintained neutrality in matters of politics. Abel Malsira, however, reacted to the malign endeavours envisioned by the invading godos and planned appropriately to undo them. In the same way, Blest Gana's socio-political views were always there, but they were camouflaged under different layers of the narration, as if the author had sensed that his work would be scrutinised and figuratively passed under the eyes of the Index Librorum Prohibitorum (in the guise of Miguel de Cervantes's narration in Don Quijote, 1605, 1615). In his novels, the characters are involved in a plethora of political upheavals, but these are obscured behind a variety of business affairs and the ups and downs of love. Aware of his public, Blest Gana made himself heard in a unique manner as he commented on Chile's malfunctioning social organisations and promoted the levelling of hierarchies and access to education (Vilches, Blest Gana 142). In a Cervantesque turn, then, Blest Gana punctured many holes in the Chilean social fabric via sarcastic narratives exposing the injustice of his own society and its pervasive and corrosive love of money.

\section{Blest Gana at 100}

Blest Gana made it his business to write about Chile, its citizens' customs, their strengths, and weaknesses. After his diplomatic career, when he resumed creative writing, he incorporated other societies into his work. He confessed to his friend Benjamín Vicuña Mackenna that his call to arms came from prose

desde un día en que leyendo a Balzac, hice un auto de fe en mi chimenea, condenando a las llamas las impresiones rimadas de mi adolescencia, juré ser novelista, o abandonar el campo literario si las fuerzas no me alcanzaban para hacer algo que no fuesen triviales o pasajeras composiciones [after reading Balzac, I performed an auto da fé in my fireplace, condemning the rhyming impressions of my adolescence to the flames. I vowed to be a novelist and to leave the literary field if I did not possess the strength to produce something more than just trivial and transient compositions] (Epistolario 14; 36).

Drawing on all his diverse experiences, Blest Gana made himself an author and became a literary founder of the Chilean nation.

Blest Gana's immense curiosity about his country's mores went as far as to include the ways in which Chileans received medical treatment. Raised by an eminent physician, from a young age the author came into contact not only with his father's professional acquaintances but also with illness and death. Various of his novels reveal a dichotomy between "primitive" medicine and new, scientifically driven treatments and thus portray how the nation was moving forward and becoming modernised. In Chile, the professionalisation of physicians meant that doctors had to compete fiercely with individuals who had practiced medicine in a sui generis manner for generations. These included "yerbateros, curanderos, meicas [herbalists, medicine persons, healers], etc." (Serrano 187). Such socio-medical divisions can be seen in La aritmética en el amor, El ideal de un calavera, and El loco Estero (1909), for example. Like a cultural anthropologist, therefore, Blest Gana recorded people's daily habits and particularities. We see this especially clearly in those episodes where, with amusement or disapproval, he praises or condemns behaviour that impacted the developing nation (Vilches, Blest Gana 142).

The essays gathered here intend to re-open and continue an energising dialogue. Contributors focus on variegated features of the Blest Gana oeuvre, from historical and spatial aspects to modernity and affect. For practical purposes, this special edition of Open Cultural Studies follows a chronological order based on the dates of Blest Gana's publications. It should be emphasised from the outset that in order to preserve and convey the flavour of Blest Gana's writing, each essay quotes him directly in the original Spanish, accompanied by English translations. On rare occasions, this approach has been extended to other authors in specific circumstances for purposes that include clarity and emphasis and in order to account for the nuances of translation. Capturing the nuances of Blest Gana's language and communicating them in contemporary English is no easy task. I would like, therefore, to acknowledge the diligent, patient work of Gerald Seaman who assisted with the translations and with manuscript editing in general. 
Juan Poblete's Foreword, On Alberto Blest Gana, opens the discussion for this special edition. Throughout his career, the pioneering cultural critic has produced ground-breaking work on a wide range of literary and cultural subjects. This includes reflections on the social mores and reading practices of nineteenthcentury Latin America. Here, he focuses specifically on the different ways in which Blest Gana can be read. Emphasising that reading fiction is a symbolic act of nation building, Poblete addresses the different levels and cultural processes that are at play in the making and production of a Chilean national novel.

The opening essay by Hernán Pas examines the role of the print press: "From the Newspaper Serial to the Novel (1853-1863): Mediation of the Periodical Press in the Foundation of Alberto Blest Gana's Narrative Project.” After 1850, works of fiction by foreign or national authors initiated a process of mass circulation through folletines, which appeared in the most prominent newspapers in Chile and attracted an audience that included young people and women (Cánepa 249). This medium allows Pas to inquire into the aesthetic protocols of the Chilean press, which was the space where Blest Gana primarily published his early works. The sentimental folletines, mostly by French authors, contributed to the birth of the novel in Chile by making readers eager consumers of that genre. Indeed, Chilean authors applied structural motifs from the folletines as signposts in their own fiction, not as a way of competing with European authors but as a way of translating and adapting those motifs to the national stage (Poblete, Literatura 23, 46). Pas concentrates on Blest Gana's first narrative period, starting with his early fiction which featured works such as Una escena social [A Social Scene] (1853) and Un drama en el campo [A Drama in the Countryside] (1859). Pas also delineates how, with his famous works Martín Rivas and El ideal de un calavera, Blest Gana carved out a space for himself while competing with foreign authors who also published in folletines. The result was new, national readership, and attention.

In "Alberto Blest Gana and the Sensory Appeal of Wealth,” Patricia Vilches investigates Blest Gana's award-winning La aritmética en el amor from the critical perspectives of sense and affect. Set in 1858, the novel narrates the ups and downs of modernisation. The essay contends that the characters, in their everyday lives, habits, and desires, reproduce the marketing preferences of mid-nineteenth-century Chileans. In Santiago, new fortunes are being made fast and/or old ones are being lost by volatile markets; hence, even the perennial well-to-do may have to adjust their lives. For the new rich in this capitalist space, luxury items and exuberant events and spaces are essential elements of their identity. Since they do not possess proper upper-class last names, they squander their money in a relentless effort to look the part of someone who does (Sasso 102). From the moment Fortunato Esperanzano, the novel's protagonist, steps out into the city, he finds himself enjoying the puff of a cigarette and the sight of a beautiful woman. He not only sees her and appreciates her impeccable features but also hears the beautiful soundscape of her expensive clothes. Throughout the novel, the external trappings of the affluent, especially their expensive possessions, stimulate in others a desire for the good things in life: a gorgeous spouse, delicate ornaments, fabrics, jewellery, that is, the material things that wealth brings to people and which, in turn, play a prominent role in maintaining the social order.

“New Problems of Realism in Martín Rivas,” by Ignacio Álvarez, considers the critics' view of Blest Gana's most successful novel as a vehicle of literary realism, divorced from a so-called exotic path of romanticism or dramatic sentimentalism. Within the framework of critics such as Northrop Frye, Doris Sommer, Jaime Concha, Erich Auerbach, and Ian Watt, Álvarez addresses his critical readings of Martín Rivas from the standpoint of a partial realism that goes hand in hand with an oblique romantic expression. With this hybrid approach, the novel can be distinguished from other so-called realistic work and thus understood as a vessel wherein history, politics, and romance happily coexist and are intertwined. The essay also contends that the novel forms a literary transition from European models to the stage of Chilean national literature where Martín Rivas enjoys enduring prominence in Chile's national imaginary. The novel thus provides Chileans with "the technical means for 'representing' the kind of imagined community that is the nation" (Anderson 25) and sets the standard for the novela de costumbres [novel of manners] in Chile. With this insight, Álvarez encourages further research on Blest Gana under a similar light while also noting that it may be used to elucidate the works of his contemporaries, such as Alberto el jugador (1860) by Rosario Orrego de Uribe. 
Luigi Patruno in "What about Realism? Alberto Blest Gana, Georg Lukács, and Their Chilean Readers" also interrogates Martín Rivas as a text once believed to be constructed according to a precise system of standards and conventions. Traditionally, the novel has been regarded as engaging with broad features of realism. Any textual propensity for, or critical engagement with, romanticism or other genres has thus been marginalised. The essay recreates a sort of dialogue between two prominent Blest Gana scholars, Jaime Concha and Ricardo Latcham; each perceives Blest Gana's work, according to Patruno, from the perspective of the theories of the philosopher and literary historian Georg Lukács, explicitly or implicitly. In Studies on European Realism, the Hungarian critic declares that the narrative technique of "realism" allows for a novel to recount facts as they are, without idealisation or abstraction. Characters from such a novel replicate the totality of a society; that is, the writer of "realism" functions as a recorder of events who provides "a three-dimensionality, and all-roundedness" through which characters present their own world (6). In this regard, we could say that Martin Rivas reconstructs the social conditions of the 1850s in Chile while juxtaposing human interaction and material conditions. Patruno reviews how traces of Lukács are evident in the novel's historical-social processes as discussed by Concha and Latcham.

Laura Janina Hosiasson in "Alberto Blest Gana: Four Chronicles and a Novel" examines the author's short novel, Mariluán, as well as his journalistic writings in op-eds concerning the negotiations between Chilean criollos and the Mapuche. The historical subject matter for the novel and Blest Gana's chronicles is the adjudication and jurisdiction of a geographical space in southern Chile. The nation's decision to establish quickly and forcibly its sovereignty over its territories in the Patagonia was triggered in part by an audacious act. In 1860, French citizen Orélie-Antoine de Tounens declared that Patagonia did not belong to any state. Because it was autonomous, he proclaimed himself the king of Patagonia, the "Royaume d'Araucanie et de Patagonie, 'by the Grace of God and the will of the Mapuche”' (Sepúlveda 357). In 1862 Chileans and citizens of Araucanía took action to redefine their own conception of a previously neglected, liminal space. A group of caciques [chieftains] travelled to Santiago to discuss the geographical borders between Araucanía and the Chilean nation (Bengoa 199). Hosiasson illuminates Blest Gana's socio-political views as they were revealed in his "Conversación del sábado" [Saturday's Conversation], which appeared in the newspaper La voz de Chile. She also discovers a deep relationship between the author's two voices, one belonging to a novelist and the other to a journalist, as she assesses Mariluán over and against his Saturday chronicles.

“Countering Acts of Dispossession through Alberto Blest Gana's Mariluân,” an essay by Angela N. DeLutis-Eichenberger, contemplates the tragic figure of Fermín Mariluán, the novel's main character. Fermin is the son of the powerful Cacique Ruler Francisco Mariluán who had fought on the side of the crown during the wars of independence. In his conduct, he embodied what most Mapuche feared about the Chilean criollos, their facility to break their word. He found that Chileans were persistently intent on advancing on his territories and others. By contrast, he entrusted his son's education to a Chilean school on the other side of the Bío-Bío River. Fermín "became" Chilean, fighting for Chile during the war against the Peru-Bolivia Confederation in 1839 (Bengoa 85, 86). DeLutis-Eichenberger's exploration of Fermín's character focuses on his being deterritorialised and dispossessed. The "dispossessed" subject, in this context, is defined as "one that avows the differentiated social bonds by which it is constituted and to which it is obligated" (Butler and Athanasiou ix). Torn by his love for Rosa Tudela, a Chilean criolla, the protagonist feels that his first patria is Arauco. An intelligent and courageous man, he seeks the perks of progress and education for his people. Dis/possession also reveals itself in the ways in which chronologies are accommodated in the narration to fit with the novel's idea of integration, as DeLutis-Eichenberger adeptly shows.

Cody C. Hanson's essay, “The Costumbrismo of Conflict in El ideal de un calavera," elaborates on the novel's numerous depictions of Chileans' customs, habits, beliefs, and attitudes, the time-honoured aspects of nineteenth-century novels that literary critics have traditionally called cuadro de costumbres. Hanson draws our attention to the novel's pervasive descriptions of established social practices in the 1830s, the chronological setting for the story. Such scenes challenge and, to an extent, even subvert the narration itself. Following the theories of Mikhail Bakhtin and Antonio Cornejo Polar, among others, the essay argues that the narrative functions within a chronotrope, time-space connectedness, summoning how Chilean national identity has been created "to the letter." For Hanson, this creation reveals a hegemonic contradiction. The essay interrogates the customs of the "parlour" and the "rodeo" (portrayed in detail in the novel) and thus underscores how the 
customs themselves erase traces of social class. They denote a deep level of social detachment on the part of Abelardo Manríquez, the protagonist, as well as the selfish ambitions of wealthy characters. On the one hand, this portrait of a nation's customs engenders a shared experience, in the sense of Anderson's "imagined communities" (13); on the other, the narration grinds on oppositions, on class division and rural versus urban living. This illustrative ambiguity allows for a new, critical reading of the novel and Chilean national identity.

"Paris, the End of the Party in Alberto Blest Gana's Los Trasplantados," by Alvaro Kaempfer, explores the socio-cultural conflicts endured by the Canalejas, a Spanish-American family who has the means to travel and take up residence in Paris. In Los Trasplantados, as the title itself implies, Blest Gana wrote about individuals who made the City of Lights their "transplanted" home. The novel has been read by critics as accentuating issues of human ambition and conflict, "not necessarily triggered by poverty or social injustice” (Durán Luzio 916). Kaempfer's analysis shows how the Canalejas are favoured by and, at the same time, subjected to modernisation, with members of the family responding differently to the pulse of progress. The family must contend with the prejudices of Europeans who see them as mere rastaquouères, social upstarts from Hispano America. The young Mercedes Canalejas is followed from "allâ" (Hispano America) to Paris by the handsome Patricio Fuentealba. They love each other. But the wealthy Canalejas are on a collision course with the impoverished bourgeoise, incarnated by Fuentealba, a Martin Rivas-type character who does not, however, achieve any of the latter's success (Araya 47). The family is enamoured of everything "chic" and rejects anything that comes from their old world. Kaempfer weighs in on how certain social conditions and aspirations, such as the right place to live, the right car to have, the right social event to attend, or the right skin colour are shaped by the interconnections of colonialism and globalisation.

\section{Blest Gana, Sociability, and Père Lachaise}

Blest Gana gave his readers paradigms of optimal (or flawed) social comportment. He also acknowledged and revealed the inevitable changes wrought by modernity via his characters' behaviours and desires. For instance, Martín Rivas's choice of career has taught all of Chile that a Law degree in the nineteenth-century was "a vehicle of social advancement for those who had neither a house nor property, capital or interest" (Serrano 164). As well, Leonor Encina's iconic piano playing during the tertulias articulates not only the advantages of an educated woman but also the socio-cultural changes that were occurring in that urban, modernised space (Peña 23). The Blest Gana project implicated a nation in the contrivance of tenets of social aspiration, especially those arising from European blueprints. This project was shared by other contemporary intellectuals who saw it as their patriotic duty to change, renovate, reenergise, and adopt more cosmopolitan habits. These included new ways of educating citizens as well as new political philosophies for governing the nation. Poblete's analysis has shown that this phenomenon derives mostly from "what Spanish American historiography recognises as a precedence of the state over the nation" (Literatura 65). ${ }^{10}$ Encouraged by his own status as a writer and public figure in Chile, and in keeping with the traditional social signposts that he set out from the beginning of his creative career, Blest Gana made a commitment to impact the taste and passions of his readers (82). In the national project, sociability was essential for Chileans at home and abroad.

When he retired from his post as a diplomat in 1887, Blest Gana carried on with his career as a creative writer free from other professional obligations or impediments. He was left with the option of returning to Chile or staying in Paris. His job no longer required him to be in permanent residence in France. Hernán Poblete Varas, one of his biographers, wonders whether the author ever considered returning to his

10 Poblete argues that conceiving sociability took into account a "Creative mimesis or imitation" that derived from the "paradigms of successful societies." The critic also alludes to a decisive aspect of Chilean sociability (and other parts of Latin America) during the second half of the nineteenth-century, which became expressed in "writing and reading of letters, poems, dedications, newspapers, serialised novels, [and] novels" (Literatura 66-68). 
homeland and whether he just kept postponing his departure. Like the characters in Los Trasplantados, the author's children had made Paris their second home; in some cases, it was actually their birthplace. One of his grandchildren eventually became a member of the French military, following in the footsteps of his grandfather. At that point in his life, Chile had perhaps become "a hypothesis," an idea transmitted to him through letters (Álvarez 131). A return, therefore, was most likely never an option. Indeed, most of his relatives and acquaintances were already gone. Leaving Paris would have meant uprooting himself and his family. Increasingly, Chile had become part of a distant past (Poblete Varas 208, 248).

The author figuratively returned to his place of birth with Durante la Reconquista and El loco Estero. The latter novel, with the additional title of Recuerdos de la niñez [Remembrances from Childhood], revealed in a subtle way (through descriptions of ornaments and furniture, in particular) that the house of "Don Guillén" was inhabited by people of British descent. The narration commemorates the Battle of Yungay (1839) and clings tightly to nostalgic reflections about a weighty past: "El pasado reclama siempre su parte, por deliberado que sea el propósito de apartarlo en las combinaciones del porvenir" [The past always claims its share, no matter how deliberate our intentions may be to set it aside in the shape of things to come] (Blest Gana, El loco Estero 313). In 1916, Blest Gana wrote to his sister: "Te agradezco los recuerdos de familia que me comunicas en tu carta. Con la imaginación vivo mucho más del pasado que del presente” [I would like to thank you for the family memories that you have mentioned in your letter. In my imagination I live much more in the past than in the present] (Epistolario 831; 975). He was greatly affected by the death of Carmen Bascuñan, his wife of 57 years. Carmen had been his best friend and advisor and she was instrumental in his whole writing process (Silva Castro, Blest Gana 145; Poblete Varas 51, 52). After her passing, Blest Gana ceased to write fiction and died 9 years later.

One may contemplate the meaning of Blest Gana's resting place in Paris: "if people cannot be buried or visited in memory in a place that they called their 'home,' can it really be designated as such"? (Odland and Martin 42). Concerning the author's grave in a foreign land, Poblete Varas exclaims: "Blest Gana continues to be absent, exiled. But alive, prodigiously alive, among those who still today, with deep emotion, follow the whirlwind of his works" (254). Raúl Silva Castro, another one of his biographers, also reflects upon Blest Gana's peculiar burial space, “And this man who so loved his country and who selflessly gave his whole life to it, rests in a foreign land" ("La obra" 335). Knowing that a precise answer will remain forever elusive, we should nonetheless ask ourselves the following: To what extent is Père Lachaise Blest Gana's legitimate home? What did it mean (when he died) and what does it mean now to Chileans that Père Lachaise is "our" writer's final resting place? According to Nora, cemeteries as lieux de mémoire are spaces, that like "gestures, images, and objects" construct continuity in a nation (9). They appear at the crossroads of a national history, from a single, partial discourse that becomes a legacy for all; that is, a universal, "collective discourse" (22). We must never forget that there is a spatial relationship that exists between the living and the dead; cemeteries, after all, are also for the living. We who remain need calming, accessible spaces to reach and visit our dead (Odland and Martin 47). In this connection, the essays compiled in Blest Gana at 100 are a means of paying our respects and commemorating the author's 100 years at Père Lachaise. The contributors have accomplished this by using fresh approaches to revisit what critics have said about Blest Gana in the past; analysing works that have received less critical attention; and mapping out alternative critical strategies in Blest Gana studies. Their greater purpose, of course, is to inspire and continue a robust multi-disciplinary discussion of the Chilean author's life and work for the next 100 years and beyond.

Conflict of interest: Author states no conflict of interest.

\section{Works Cited}

Alone (Díaz Arrieta, Hernán). Don Alberto Blest Gana; biografía y crítica [Don Alberto Blest Gana: Biography and Critique]. Nascimento, 1940. 
Álvarez, Ignacio. "Los Trasplantados o el realismo viajero de Alberto Blest Gana” [The Transplanted or the Travelling Realism of Alberto Blest Gana]. Revista chilena de literatura, no. 102, 2020, pp. 123-137. JSTOR, http://www.jstor.org/stable/26954635.

Anderson, Benedict R. Imagined Communities: Reflections on the Origin and Spread of Nationalism. Verso. Kindle edition, 2006.

Araya, Guillermo. “Historia y sociedad en la obra de Alberto Blest Gana” [History and Society in Alberto Blest Gana's Oeuvre]. Revista de crítica literaria latinoamericana, vol. 7, no. 14, 1981, pp. 29-64. JSTOR, http://www.jstor.org/stable/4530023.

Arteaga y Alemparte, Justo, and Domingo Arteaga y Alemparte. Los constituyentes de 1870 [Constituents of 1870]. Libertad, 1870. PDF e-book, https://archive.org/details/losconstituyente00arte.

Barraza, Eduardo. "La tradición del folletín y de la novela popular en Chile (cánon y corpus en la narrativa chilena siglos xix y xx)" [The Tradition of the Serial and the Popular Novel in Chile (Canon and Corpus in Nineteenth- and Twentieth-Century Chilean Narrative)]. Revista Chilena de Literatura, no. 96, 2017, pp. 115-140. JSTOR, https://www.jstor.org/stable/10. $2307 / 90016184$.

Bengoa, José. Historia del pueblo mapuche: Siglos XIX y XX [History of the Mapuche People: Nineteenth and Twentieth Centuries]. LOM, 2000.

Blest Gana, Alberto. Epistolario de Alberto Blest Gana: 1856-1916 [Alberto Blest Gana's Epistolary: 1856-1916], edited by José Miguel Barros Franco, DIBAM, 2011.

Blest Gana, Alberto. “Literatura chilena. Algunas consideraciones sobre ella.” Discurso de don Alberto Blest Gana en su incorporación de la Facultad de Filosofia y Humanidades, el 3 de enero de 1861 [Chilean Literature. Some Considerations. Speech by Alberto Blest Gana on the Occasion of His Selection to the Faculty/School of Philosophy and Humanities on 3rd January 1861]. Anales de la Universidad de Chile, 1861, https://anales.uchile.cl/index.php/ANUC/article/view/3177/3089.

Blest Gana, Alberto. El loco Estero [Crazy Estero]. 5th ed., Zig-Zag, 2009.

Blest Gana, Alberto. Martín Rivas: Novela de costumbres político-sociales [Martín Rivas: A Novel of Socio-Political Manners], edited by Guillermo Araya, Ediciones Cátedra, 1981.

Butler, Judith, and Athena Athanasiou. Dispossession: The Performative in the Political. Polity Press, 2013.

Cánepa, Gina. "Folletines históricos del Chile independiente y su articulación con la novela naturalista” [Historical Feuilletons of Independent Chile and Their Articulations with the Naturalist Novel]. Revista de Crítica Literaria Latinoamericana, vol. 15, no. 30, 1989, pp. 249-258. JSTOR. doi:10.2307/4530468.

“Clotario Blest Riffo (1899-1990)." Memoria chilena. Biblioteca Nacional de Chile, n.d., http://www.memoriachilena.gob.cl/ 602/w3-article-572.html. Accessed 7 August 2020.

Collier, Simon, and William F. Sater. A History of Chile, 1808-2002. 2nd ed., Cambridge UP, 2004.

Concha, Jaime. "Martín Rivas o la formación del burgués" [Martín Rivas or the Making of a Bourgeois]. Revista chilena de literatura, no. 5/6, 1972, pp. 9-36. JSTOR, http://www.jstor.org/stable/40355893.

Constable, Pamela, and Arturo Valenzuela. A Nation of Enemies: Chile under Pinochet. W.W. Norton \& Company, 1991.

Durán Luzio, Juan. "Entre el infierno y el cielo: Dos obras de la narrativa chilena en 1904" [Between Hell and Heaven: Two Works of Chilean Narrative in 1904]. Revista Iberoamericana vo. LX, no. 168-169, 1994, pp. 915-924. doi:10.5195/ reviberoamer.1994.6446.

Gotschlich, Guillermo. El realismo en la novelística de Blest Gana [Realism in the Fiction of Blest Gana]. RIL, 1992.

Hosiasson, Laura J. "Alberto Blest Gana and Clotario Blest. Literary and Political Legacy of an Irishman in Chile." ABEI Journal, vol. 20, 2018, pp. 39-49. doi:10.37389/abei.v20i1.3113.

Hosiasson, Laura J. “Blest Gana: El caleidoscopio inicial” [Blest Gana: The Initial Kaleidoscope]. Revista chilena de literatura, no. 102, 2020, pp. 139-162, https://scielo.conicyt.cl/pdf/rchilite/n102/0718-2295-rchilite-102-00139.pdf.

Jaksić, Iván, and Juan Durán Luzio. Prologue to Durante la Reconquista: Novela histórica [During the Reconquest: An Historical Novel], by Alberto Blest Gana. Editorial Universitaria, 2010, pp. 13-18.

Kinsbruner, Jay. Bernardo O’Higgins. Twayne Publishers, 1968.

Lastarria, José Victorino. Literary Memoirs, translated by R. Kelly Washbourne. Oxford UP, 2000.

Latcham, Ricardo A. "Blest Gana y la novela realista" [Blest Gana and the Realist Novel]. Anales de la Universidad de Chile, vol. 116, no. 112, 1958, pp. 30-46.

Lukács, Georg (György). Studies in European Realism. Grosset and Dunlap, 1964.

Nora, Pierre. "Between Memory and History: Les Lieux de Mémoire.” Representations, vol. 26, Spring, 1989, pp. 7-24, JSTOR. doi:10.2307/2928520.

Odland, Aaron, and Frank Edgerton Martin. "Reconnecting with the Urban Dead." Landscape Architecture Magazine, vol. 100, no. 6, 2010, pp. 42-49. JSTOR, http://www.jstor.com/stable/44792083.

Peña, Cármen. “El piano de Leonor: Una mirada a la interpretación musical de la heroína de Martín Rivas” [Leonor’s piano: A Look at the Musical Interpretation of the Heroine of Martín Rivas]. Resonancias, no. 26, 2010, pp. 21-39, https:// repositorio.uc.cl/handle/11534/4554?show=full.

Poblete, Juan. Literatura chilena del siglo XIX: Entre públicos lectores y figuras autoriales [Chilean Literature of the Nineteenth Century: Between Reading Publics and Authorial Figures]. Editorial Cuarto Propio, 2003.

Poblete, Juan. "Reading National Subjects." A Companion to Latin American Literature and Culture, edited by Sara Castro-Klarén, Blackwell, 2008, pp. 309-332.

Poblete Varas, Hernán. Alberto Blest Gana y su obra [Alberto Blest Gana and His Oeuvre]. Pehuén, 1995. 
“Recursos educativos” [Educational Resources]. Curriculum Nacional, n.d., https://www.curriculumnacional.cl/614/ w3-article-77518.html. Accessed 13 August 2020.

Roselli, Alyssa. Cementerio General de Santiago: Chile's Grand and Historic Cemetery, 14 Sept. 2014, http://santiagotourist. com/cementario-general-de-santiago-chiles-grand-and-historic-cemetery/. Accessed 14 August 2020.

Sasso Olivares, Ilse. Mujer chilena: Identidad y textos publicitarios [Chilean Women: Identity and Advertising Texts]. Ediciones Unicornio, 1998.

Sepúlveda, Alfredo. Breve historia de Chile [A Brief History of Chile]. Santiago, Random House Mondadori, 2018. PDF e-book. Serrano, Sol. Universidad y nación: Chile en el siglo XIX [University and Nation: Chile in the Nineteenth Century]. Editorial universitaria, 1994.

Silva Castro, Raúl. Alberto Blest Gana, 1830-1920. Zig-Zag, 1955.

Silva Castro, Raúl. “La obra novelística del chileno Alberto Blest Gana” [The Fiction of Chilean Alberto Blest Gana]. Cuadernos Hispanoamericanos, no. 90, 1957, pp. 324-346, http://www.cervantesvirtual.com/obra/la-obra-novelistica-del-chilenoalberto-blest-gana/. Accessed 8 August 2020.

Sommer, Doris. Foundational Fictions: The National Romances of Latin America. U of California P, 1991.

Subercaseaux, Bernardo. Historia de las ideas y de la cultura en Chile [History of Ideas and Culture in Chile]. Volumen I. Editorial Universitaria, 1997.

Vilches, Patricia. Blest Gana via Machiavelli and Cervantes: National Identity and Social Order in Chile. Cambridge Scholars Publications, 2017.

Vilches, Patricia. “Martín Rivas, Maquiavelo y masculinidad decimonónica chilena” [Martín Rivas, Machiavelli and NineteenthCentury Chilean Masculinity]. Anales de Literatura Chilena, no. 13, 2010, pp. 69-88. 